\title{
Effect of Think-Pair-Share Instructional Strategy on Students' Achievement in Civic Education in Bayelsa, Nigeria
}

\author{
AbdulRaheem Yusuf \\ Department of Social Sciences Education, Faculty of Education, University of Ilorin, Ilorin, Nigeria, \\ yuabra@unilorin.edu.ng
}

Victory Collins Owede

Department of Social Sciences Education, Faculty of Education, University of Ilorin, Ilorin, Nigeria, victoryowede@gmail.com

\section{Muhinat Bolanle Bello}

Department of Social Sciences Education, Faculty of Education, University of Ilorin, Ilorin, Nigeria, muhinat4islam@yahoo.com

\footnotetext{
The major purpose of the study was to investigate the effect of Think-Pair-Share instructional Strategy on secondary school students' achievement in Civic Education in Bayelsa State, Nigeria. The study adopted a quasi-experimental $2 \times 2 \times 3$ pre-test,-post-test factorial design. All the SSS II students in Bayelsa State constituted the target population. Intact classes of 61 and 46 students were purposively sampled for the experimental and control groups respectively. Three researcher-designed instruments which included two instructional packages and one Test were used to collect data for the study. Reliability index of the Civic Education Achievement Test was 0.83 obtained through a test re-test method after an interval of two weeks using Pearson's Product Moment Correlation while Analysis of Co-variance (ANCOVA) statistic was used to test three research hypotheses at 0.05 level of significance. Findings from this study revealed among others that students taught Civic Education using Think-Pair-Share strategy outperformed those in the control group. There is no significant effect of treatments on secondary school students' achievement in Civic Education based on gender. Based on the findings, the study recommended among others that teachers should engage all categories of students in active learning where students' previous experiences are explored to recreate new knowledge.
}

Keywords: think-pair-share, strategy, student-centered, civic education, achievement, instructional strategy

\section{INTRODUCTION}

Think-Pair-Share teaching strategy which emerged in the late 1980s is described by many as a cooperative learning strategy which encourages individual students to engage in critical thinking and cooperates with others in the process of knowledge construction (Sampsel, 2013; Bamiro, 2015). ThinkPair-Share as the name implies, provide an opportunity for the individual student to think (reflect) on a question or problem asked by the teacher, then pair up with other students in a cooperative manner to brainstorm on a possible answer. The learning process is concluded by allowing the student to share their discoveries, answers, and solutions with the whole class. In a classroom setting typical of ThinkPair-Share learning strategy, both the cognitive and social dimensions of learning are nourished which eventually leads to discoveries and new knowledge.

Citation: Yusuf, A. R., Owede, V. C., \& Bello, M. B. (2018). Effect of Think-Pair-Share Instructional Strategy on Students' Achievement in Civic Education in Bayelsa, Nigeria. Anatolian Journal of Education, 3(2), 47-62. https://doi.org/10.29333/aje.2018.325a 
For example, Ledlow (2001) and Saskatoon Public School (2009) are or the view that using ThinkPair-Share during classroom instruction increases the rate of response and participation by students compared to the traditional (lecture) method. Also, the wait time between think and pair enables students to critically reflect on a wide range of possible answer to a question by formulating their ideas and validating those ideas with their classmates (Schreyer Institute for Teaching and Learning, 2007; Sampsel, 2013). In fact, Sampsel (2013) reported that the use of Think-Pair-Share strategy goes a long way in boosting student' confidence in classroom discussion and participation. Again, research has also shown that Think-Pair-Share strategy can be applied or used in any subject area or class size (Hollyjamaludin, 2012). With Think-Pair-Share strategy, students were found to record high grades or scores in their achievement level in school subjects when compared to the traditional (Lecture) method.

For instance, Ofodu and Lawal (2011) in their experimental study on the effect of Think-Pair-Share and Reciprocal teaching methods on the performance and of students in the English Language found that junior secondary school students in Ekiti who were taught reading comprehension using ThinkPair-Share strategy performed better than those taught with the traditional (lecture) method. This result was comparable to the findings of Odediji (2013) who reported that junior secondary students in Ilorin metropolis had better achievement in Social Studies when taught with Think-Pair-Share teaching strategy related to the students taught using the traditional method. However, because of its potential of consuming time Robertson (2006) suggests that the teacher's role in a Think-Pair-Share classroom should be that of trying to be a facilitator of requisite knowledge by asking thought-provoking questions that could cause students to display their creative and reflective abilities. This way, classroom discussions and interactions become more productive and engaging given the fact that the teacher on his part can learn new ideas from the students themselves.

Therefore, the need to investigate the effect of Think-Pair-Share instructional strategy on senior secondary school students achievement in Civic Education in Bayelsa State, Nigeria is informed by the fact that much of the teaching and learning activities in most school subjects in Nigeria is still being guided by the traditional (lecture) method of the teaching through verbal presentation, of facts information and ideas thereby giving little space and time for students to actively participate in the lesson. Thus, it becomes crucial for an investigation (through a quasi-experimental design) to be conducted on this learning strategy about students' achievement with specific reference to Civic Education.

However, a point that has been identified in existing literature is the influence of gender on students' academic achievement. Thus, gender is seen as a strong predictor of human conduct in the social sphere and a moderator of students' achievement level (Bamiro, 2015). Closely related to the concept of gender is the concept of career aspiration which is often reflected in students' subject combination. Research has shown that differences exist in students' academic achievement especially when what the student desire to study reflecting in the combination of subjects (i.e. Science, Arts and Commercial) selected is taken into account (Obura \& Ajowi, 2012).

Based on this premise, there is need to include gender and subject combination as possible moderators in academic achievement in Civic Education especially when students' are taught with Think-PairShare instructional strategy.

Research Questions

The following research questions were raised.

1. What is the effect of Think-Pair-Share instructional strategy on senior secondary school students' achievement in Civic Education in Bayelsa State, Nigeria? 
2. Would treatment have an effect on senior secondary school students' achievement in Civic Education based on gender?

3. What is the effect of the treatments on the academic achievement of senior secondary school students' in Civic Education on the basis of subject combination?

\section{Research Hypotheses}

To give an appropriate direction to the study, the following null hypotheses were formulated and tested:

Ho1. There is no significant effect of Think-Pair-Share instructional strategy on senior secondary school students' achievement in Civic Education in Bayelsa State, Nigeria.

Ho2. There is no significant effect of treatment (Think-Pair-Share instructional strategy) on the academic achievement of male and female senior secondary school students in Civic Education in Bayelsa State, Nigeria.

Ho3. There is no significant effect of treatment (Think-Pair-Share instructional strategy) on the academic achievement of science, arts and commercial senior secondary school students in Civic Education in Bayelsa State, Nigeria.

\section{Context and Review of Literature}

Secondary school education as conceived by the Federal Republic of Nigeria (2013) in the National Policy on Education; can best be described as a segment of the education system that serves dual purposes. This is because in one hand it serves as a preparatory stage for higher or tertiary education for those who may have the desire and potential to further their educational aspirations or careers. On the other hand, secondary education also serves as a terminal stage for those who may not want to continue to higher education or those who are not capable of continuing but may want to pursue a career in technical or vocational oriented subject areas.

Again, the formal education system in Nigeria just like other countries of the world is characterized by an evaluation system that determines the success or failure viz-a-viz placement of learners according to their performance or achievement levels. Thus, one primary criterion that has been adopted over the years by the school system is the level of achievement each student may earn for a particular subject area. That means that students' achievement determines to a large extent, the reward or promotion to be given to such a student/learner that might have higher scores or marks. In line with this understanding, Armstrong (2006) maintained that the conditions that qualify a school or an educational system to be best are measure regarding the high standardized test grades of students reflecting in a report of adequate yearly progress. This could be inferred to mean that a combination of emphasis on achievement and the development of human experience which fosters the acquisition of new skills and abilities is what characterized an education system or learning experience that is effective and result-oriented.

More importantly, standing at the centre of an effective, efficient and result-oriented education is the teacher. The teacher's actions and inactions, skills, knowledge and the medium or strategies he deploys to convey the requisite skills or knowledge goes a long way in shaping the effectiveness or otherwise of the teaching-learning process. Little wonder, Perveen (2010) opined that education cannot be more effective without effective teaching and that there are many strategies for effective teaching and an effective strategy employed by the teacher can ensure an effective learning. The point should be made here and quickly too that, effective learning translates to better achievement or learning outcome on the part of learners in all school subjects. It is also noteworthy to emphasize at this juncture that, the Nigerian school system is replete with different subjects designated as core, pre- 
vocational, vocational and elective, especially at the primary to secondary school level (FRN, 2013). Thus, among the school subjects designated as compulsory subjects for pupils and students in both primary and secondary schools in Nigeria, is Civic Education. For the avoidance of doubt, Civic Education is one of the innovative and problem solving based subjects that have been included in the Nigerian primary and secondary school curriculum in 2009.

Similarly, Nwaubani and Azuh (2014) are of the view that the inclusion and the subsequent elevation of Civic Education to the status of the compulsory subject is a clear indication of the importance of the subject in building patriotic and national conscious citizenry. The point should be made that the compulsory status presently occupied by Civic Education in both primary and secondary schools in Nigeria did not come as a surprise to many educators and public commentators who have always advocated the need for the Nigerian government to use education as a tool to halt the myriad of socioeconomic and political challenges confronting the nation. It should also be noted that since the inclusion of Civic Education in the primary and secondary school curricula and because of its compulsory status, it has become part of the examinable subjects by both the National Examination Council (NECO), West African Examination Council (WAEC) and the National Business and Technical Education Board (NABTEB) at the Senior School Certificate Examination (SSCE) since 2014.

In fact, it has been established in both theoretical and empirical literature that a combination of several teacher-related, student-related, school-related, government-related and environmental-related factors largely contributes to the good or poor achievement or performance of students in any school subject including Civic Education. In other words, the final product of student learning is the achievement level assigned in the form of grades and scores received from tests and examinations as shown in the tables above. Among the teacher-related factors influencing students' academic achievement is the type of teaching strategy or method deployed by the teacher to convey the content of the subject to the students.

In the Nigerian primary to tertiary schools, for example, teachers have used to the traditional (lecture) method of teaching where the teaching-learning process is usually dominated by the teacher (Oludipe \& Oludipe, 2010). The traditional teaching strategy, more often than not, creates a passive student audience where the teacher does the talking and writing on the chalk or white board while the students' role is to listen and copy from the board. The underlying philosophy of the traditional (lecture) method of teaching is that knowledge is fixed and the teacher is the only person that is better placed to transmit the knowledge, skills and concepts to the learner. However, this has been criticized for taking the students as a passive recipient of knowledge without taking into account the need for students' to be actively engaged in the learning process.

Against this backdrop, the European Students Union (ESU, 2010) averred that the traditional (lecture) method of teaching is more of a non-participatory strategy than an active and participatory strategy where students are not given the opportunity to ask questions, but rather they compete among themselves for grades as they prepare for tests and examinations. Based on the drawback of the traditional (lecture) method, Oludipe and Oludipe (2010) also opined that the development of students' creative skills and abilities is placed at the back seat in a typical traditional (Lecture) method classroom. Indeed, the traditional (lecture) strategy is a strategy that is adjudged to be teachercentered.

Consequently, the many identifiable weaknesses of the traditional (lecture) method such as being teacher-centered and creating passivism on the part of students; have led several researchers to come up with more result-oriented and student-centered teaching and learning strategies. Teaching strategies that placed the student at the epicenter of the teaching and learning process are supported by the constructivist theory of learning which holds that students learn better when they actively participate in 
the process of knowledge creation taking into account students' previous experiences. Though there are divergent schools of thought within the grand theory of constructivism, both the social constructivists and psychological (cognitive) constructivists, for example, are similar to their argument that learning becomes effective only when learners construct their knowledge, and by co-operating with other students (Richardson, 2003, Giesen, 2012). The role of the teacher in a typical constructivist-based classroom is to serve as a facilitator of knowledge rather than a transmitter of knowledge; to give discovery oriented tasks to students so that they can be empowered and be responsible students (Cooperstein \& Kocevar-Weidinger, 2004; Peer \& Martin, 2005). By and large, the application of constructivist theory in education has given rise to the development of new and innovative teaching and learning strategies. These strategies (including Think-Pair-Share) have over the years recorded considerable successes in classroom teaching and learning activities in America and Europe and other parts of the globe at different levels of the education system. To state the least, Think-Pair-Share strategy is an example of innovative and student-centered instructional strategy.

Empirically, Jebur, Jasim and Jaboori (2012) in a post-test control group quasi-experimental design involving 40 year one students in an Iraqi university; found that there is significant difference in the achievement of students in General English taught with Think-Pair-Share than those taught with a traditional instructional strategy. Secondly, in Indonesia, Mafan and Marhaeni (2013) conducted an experimental study with a $2 \times 2$ factorial design post-test only to find the effect of Think-Pair-Share strategy on the English reading achievement of students on the basis of achievement motivation. Their findings revealed the following among others:

1. Significant difference exists between the set of students taught with Think-Pair-Share strategy and the set of students taught with a conventional instructional strategy.

2. There was an interactive effect between Think-Pair-Share and achievement motivation of students towards English reading.

3. There exist significant difference in English reading achievement between the students with high achievement taught with Think-Pair-Share teaching strategy and students taught with conventional instructional strategy.

In a similar vein, Utama, Marhaeni and Putra (2013) conducted an experimental study with a post-test control group with 121 second grade students in Singaraja, Indonesia; and found that Think-pair-Share instructional strategy had significant effect on students' self-confidence and speaking competency in English language. Here in Nigeria, Odedeji (2013) also conducted a quasi-experimental research on the effect Think-Pair-Share instructional strategy on students' performance in Social Studies in Junior Secondary Schools in Ilorin, Nigeria; with 96 JSS II students as sample. Her findings revealed that students who were taught with Think-Pair-Share instructional strategy performed better than those taught with conventional method. Also in her study, there was significant difference in the performance of students in Social Studies in terms of performance levels as a result of the use of Think-Pair-Share instructional strategy. However, there was no significance difference in performance in terms of gender.

Similarly, from a sample of 242 senior secondary school I students in a pre-test post-test, control group quasi-experimental study in Ogun State, Nigeria; Bamiro (2015) reported that there was significant higher post-test mean scores of students in Chemistry taught with Think-Pair-Share than those students taught with lecture strategy. Bamiro's Study also revealed that there was no significant main effect of think-Pair-Share on students' achievement in chemistry on the basis of gender. In Saudi Arabia, a quasi-experimental study with a sample of 70 Educational Psychology undergraduates of King Saud University in Riyadh was conducted by Bataineh (2015) who found that there was significant difference in the academic performance of undergraduate students in the post-test mean 
scores between those taught with Think-Pair-Share and those taught with traditional instructional method. The study further revealed that significant difference exists between second and fourth year students in the performance when Think-Pair-Share instructional strategy was used.

Unfortunately, many of the previous empirical studies highlighted were either done in foreign educational climes and even those studies that were conducted here in Nigeria were carried out in other secondary school subjects other than Civic Education. Hence, the need to further the knowledge frontier in this area by investigating the effect of Think-Pair-Share instructional strategy on senior secondary school students' achievement in Civic Education in Bayelsa State, Nigeria while controlling for the gender and subject combination as moderating variables.

\section{METHOD}

The research design employed in this study is quasi-experimental pre-test post-test control group factorial design due to its suitability in establishing possible cause and effect relationship. It is a nonequivalent, control group design that requires the non-random assignment of students into groups. Moreover, Cohen, Manion and Morrison (2007) argued that quasi-experimental studies provide the researcher opportunity of comparing results between groups or resulting from the naturally occurring treatment of groups. Besides, quasi-experimental studies are often used in evaluating instructional intervention or strategies due to the fact that it is practically difficult to randomly assign students to experimental and control groups (Randolph, 2008).

Hence, a factorial research design of $2 \times 2 \times 3$ was adopted to test the null hypotheses for this study. The first two factorial levels are one experimental group (Think-Pair-Share instructional strategy) and one control group (traditional instructional strategy). The second factorial level is gender occurring in either male (M) or Female (F), while the last factorial level is subject combination at three levels of Science, Arts and Commercial students. Of course, this design allowed for the experimental group to receive treatment while the control group did not receive any treatment. However, both the experimental and control groups received the pre-test and post-test before and after the treatment. The graphical expression of the experimental design is as shown in Table 1.

Table 1

2x2x3 Pre-test-Post-test-Control Groups Factorial Design on Think-Pair-Share Instructional Strategy

\begin{tabular}{lccccc}
\hline Groups (Teaching Strategies) & Pre-test & Treatment & \multicolumn{2}{c}{ Moderating Variables } & Post-Test \\
& & & Gender & Subj. Comb. & \\
\hline Experimental Group (TPS) & $\mathrm{O}_{1}$ & $\mathrm{X}_{1}$ & $\mathrm{M} / \mathrm{F}$ & Sc./Arts/Com. & $\mathrm{O}_{2}$ \\
Control Group (LM) & $\mathrm{O}_{3}$ & - & $\mathrm{M} / \mathrm{F}$ & Sc./Arts/Com. & $\mathrm{O}_{4}$ \\
\hline
\end{tabular}

\section{Population, Sample and Sampling Techniques}

Basically, the primary unit of sampling in this study is the 185 Public Senior Secondary Schools in Bayelsa State as at 2016/2017 academic session as provided by the Education Management Information System (EMIS, 2017); and not necessarily the individual students or the students' population. This is because most secondary schools (as it is also being operated in Bayelsa State secondary school system) operate an intact-group class structure. Thus, simple random sampling technique was adopted for the selection of two schools (one for experimental group and another one for the control group) in this study based on the following criteria:

a. Schools which are government owned

b. Schools which are co-educational

c. Schools where students are streamed into Science, Arts and Commercial classes

d. Schools which have the same admission policy

e. Schools not situated in the same location but located in another senatorial district. 
Mein Grammar School, Ogobiri located in Bayelsa West Senatorial District was randomly selected for the experimental group while Community Comprehensive Secondary School, Elebele located within Bayelsa East Senatorial District was randomly selected for the control group. This was done in order to ensure a balanced representation of the schools in a way.

Purposively, intact classes of second-year senior secondary school (SSS-II) students were sampled from the two secondary schools selected for the study since Science, Arts and Commercial students offer Civic Education as a compulsory subject where they are all taught in the same classroom. The reason for using intact classes of second-year senior secondary school (SSS-II) students is because they are already in their penultimate year in addition to having the opportunity of being in-depth in their exposure to Civic Education curriculum contents meant for senior secondary school given the spiral nature of the Civic Education curriculum. Also, the researchers choose intact classes of secondyear senior secondary school (SSS-II) students because they were not actively and seriously preparing for any external examination that may affect their optimum concentration during the treatment period.

Instrumentation

Three researcher's designed instruments were used to collect data for the study. The instruments include:

a. An Instructional Package (Lesson Plan) on Think-Pair-Share Instructional Strategy.

b. An Instructional Package (Lesson Plan) on Traditional (Lecture) Instructional Strategy.

c. A Civic Education Achievement Test (CEAT).

The instructional package used for the treatment group was developed based on the three phases of Think, Pair and Share which clear indicates well articulated teacher's activities and students activities while the instructional package used for the control group did not include students activities at all but reflects activities to be carried out by the teacher. Meanwhile, the Civic Education Achievement Test (CEAT) was drawn from five relevant themes (topics) in the Senior Secondary School II (SSS II) Civic Education Curriculum Scheme of Work. The topics are Dangers of Political Apathy, Achieving Popular Participation in Politics, Limitations of Human Rights, Drugs and Drug Abuse and Responsible Parenthood. The reason for selecting these five themes was that they are among the themes (topics) taught in second term as contained in the Scheme of Work for Senior Secondary School II (SSS II) Civic Education Curriculum on one hand and also falls within the period that the study was carried out on the other hand. Furthermore, the CEAT contained 50 Objectives (MultipleChoice) test items which were adapted from West African Examination Council (WAEC) and National Examination Council (NECO) past questions on Civic Education bothering on those five themes also. Though the 50 Objectives (Multiple-Choice) test items in the CEAT were carefully selected from the standardized test items derived from WAEC and NECO past questions, the face and content validity of the CEAT was still established by experts in Educational Research, Test and Measurement from the Department of Social Sciences Education, University of Ilorin, Nigeria. There inputs and suggestions were incorporated into the final draft. However, in order to establish the reliability of the CEAT, 10 copies of the final draft were trial tested to randomly selected students outside of the sampled schools through a test re-test method within an interval of two weeks. Afterwards, the Pearson's Product Moment Correlation was used to calculate the reliability coefficient which yielded a reliability index of 0.83 .

\section{Procedure for Data Collection}

The experimental group was taught using Think-Pair-Share instructional strategy for seven weeks with two periods per week making a total of fourteen periods after which the students received the post-test. The 50-items Civic Education Achievement Test (CEAT) was administered to the students as pre-test in the two selected schools before the commencement of the study and later after the treatment. Both 
the pre-test and post-test multiple choice questions were scored ' 1 ' for correct answer, and ' 0 ' for incorrect answer. That is, a total of 50 marks each for the pre-test and post test.

For the control group, the students were taught using a traditional teacher-centered strategy on the selected topics for seven weeks, with two periods per week making a total of fourteen periods after which they (the students) were exposed to the post-test. The post-test instrument contained the same items as in the pre-test but in a re-arranged form. That is, the seven weeks duration was organized based on the following:

Week One: Pre-test.

Week Two (1st Period) - Week Seven (1st Period): Students in the experimental and control groups were taught Dangers of Political Apathy, Achieving Popular Participation in Politics, Limitations of Human Rights, Drugs and Drug Abuse, and Responsible Parenthood.

2nd Period in Week Seven: Post-test.

\section{Ethical Consideration}

Firstly, in seeking the consent of the participants (SSS II students) from the sampled schools, the researchers through a note on consent, clearly informed the participants of the purpose, benefits, risks (if any) and as well as the alternatives regarding their involvement in the research. This was in addition to assuring participants of treating whatever information derived from them with utmost confidentiality. In other words, the researcher did not cajoled or deceived the students to participate in the study. Rather, it was made known to them from the beginning of the research that their participation in the study is voluntary and anyone is free to withdraw at any point during the six weeks duration of the treatment without fear of being punished or losing any possible benefit to which such participant would otherwise receive.

Secondly, it was made known to the participants that those who may be interested in knowing their scores or having access to the findings of the study at the completion of the research are free to formally make a request to the researcher personally or through their class teacher. Thirdly, in reporting the data that was collected from the participants in the form of scores derived from the Civic Education Achievement Test, participants' identities were not disclosed so as to further maintain and strengthen participants' anonymity and privacy.

\section{Data Analysis Technique}

The data collected was subjected to inferential statistics. The three research hypotheses were tested with the use of Analysis of Co-variance (ANCOVA). This enabled the researchers to adjust the posttest mean scores on the dependent variable for each of the group to compensate for the initial difference that arising from the pre-test. This was done at 0.05 level of significance.

\section{FINDINGS}

\section{Testing of Hypotheses}

Three research hypotheses were formulated and tested using Analysis of Co-variance (ANCOVA) at 0.05 level of significance. Version 20.0 of IBM SPSS (Statistical Package for the Social Sciences) was used to process the statistical analysis.

Ho1: There is no significant effect of Think-Pair-Share instructional strategy on senior secondary school students' achievement in Civic Education in Bayelsa State, Nigeria.

In testing this hypothesis, scores of the students in the prêt-test and post-test in Civic Education Achievement test (CEAT) in the experimental and control groups were collated and coded on 
statistical sheets. These scores (data) were further subjected to Analysis of Co-variance (ANCOVA) statistic at 0.05 level of significance.

Table 2

Tests of Between-Subjects Effects of Think-Pair-Share Instructional Strategy on Senior Secondary School Students' Achievement in Civic Education

\begin{tabular}{lllllll}
\hline \multicolumn{2}{l}{ Tests of Between-Subjects Effects } & \multicolumn{1}{l}{} \\
\hline Dependent Variable: & Post-test & & & & & \\
Source & Type III Sum of Squares & Df & Mean Square F & Sig. \\
Corrected Model & $6298.536 \mathrm{a}$ & 2 & 3149.268 & 95.749 & .000 \\
Intercept & 3335.363 & 1 & 3335.363 & 101.407 & .000 \\
Test1 & 795.480 & 1 & 795.480 & 24.185 & .000 \\
Group & 4417.479 & 1 & 4417.479 & 134.307 & .000 \\
Error & 2565.489 & 78 & 32.891 & & \\
Total & 75715.000 & 81 & & & & \\
Corrected Total & 8864.025 & 80 & & & &
\end{tabular}

R Squared =.711 (Adjusted R Squared $=.703$ )

Table 2 shows the result of a one-way between-group analysis of covariance conducted to determine the effect of Think-Pair-Share instructional strategy on senior secondary school students' achievement in Civic Education in Bayelsa State, Nigeria. There was a significant difference between the post-test scores of experimental and control groups on Civic Education achievement test, $(\mathrm{F}(2,81)=134.307$, $\mathrm{P}=.000, \mathrm{p}<.05$, partial eta squared $=.711)$. It is observed that the mean score of the control group increased from 19.57 to 20,79 . The mean gain score of the experimental group was able to improve from 23.20 to 37.28. Since P value is less than .05, the stated null hypothesis is rejected. Therefore, this result concludes that there is significant effect of Think-Pair-Share instructional strategy on senior secondary school students' achievement in Civic Education in Bayelsa State, Nigeria.

Ho2: There is no significant effect of Think-Pair-Share instructional strategy on the academic achievement of male and female senior secondary school students in Civic Education in Bayelsa State, Nigeria.

In testing this hypothesis, scores of the students in the prêt-test and post-test in Civic Education Achievement test (CEAT) in the experimental and control groups were collated and coded on statistical sheets on the basis of gender. These scores (data) were further subjected to Analysis of Covariance (ANCOVA) statistic Test of Between-Subjects at 0.05 level of significance and it can be seen in Table 2. 
Table 3

Tests of Between-Subjects Effects of Treatment on Academic Achievement of Male and Female Senior Secondary School Students in Civic Education

\begin{tabular}{llllll}
\hline Tests of Between-Subjects Effects & \multicolumn{7}{l}{} \\
\hline Dependent Variable: & Post-test & & & & \\
Source & Type III Sum of Squares & Df & Mean Square F & Sig. \\
Corrected Model & $1903.557 \mathrm{a}$ & 2 & 951.779 & 10.666 & .000 \\
Intercept & 1823.970 & 1 & 1823.970 & 20.440 & .000 \\
Test1 & 1876.463 & 1 & 1876.463 & 21.028 & .000 \\
Gender & 22.501 & 1 & 22.501 & .252 & .617 \\
Error & 6960.467 & 78 & 89.237 & & \\
Total & 75715.000 & 81 & & & \\
Corrected Total & 8864.025 & 80 & & & \\
\hline
\end{tabular}

R Squared $=215$ (Adjusted R Squared $=.195$

Table 3 shows effect of Think-Pair-Share instructional strategy on the academic achievement of male and female senior secondary school students in Civic Education in Bayelsa State, Nigeria. After partial out the effect of pre-test scores (Covariate), there was no significant difference in the academic achievement of male and female senior secondary school students in Civic Education, $(\mathrm{F}(2,81)=$ $.617, \mathrm{P}=.252, \mathrm{p}<.05$. Since $\mathrm{p}$ - value is greater than .05 , we therefore accept the stated null hypothesis. Therefore, the result concludes that there is no significant effect of think-Pair-Share instructional strategy on the academic achievement of male and female senior secondary school students in Civic Education in Bayelsa State, Nigeria

Ho3: There is no significant effect of treatment think-Pair-Share instructional strategy on the academic achievement of science, arts and commercial senior secondary school students in Civic Education in Bayelsa State, Nigeria.

Table 4

Tests of Between-Subjects Effects of Treatment on Academic Achievement of Science, Arts and Commercial Senior Secondary School Students in Civic Education

\begin{tabular}{llllll}
\hline Tests of Between-Subjects Effects & & & & & \\
\hline Dependent Variable: & Post-test & & & & \\
Source & Type III Sum of Squares & Df & Mean SquareF & Sig. \\
Corrected Model & $2688.824 \mathrm{a}$ & 3 & 896.275 & 11.176 & .000 \\
Intercept & 2452.477 & 1 & 2452.477 & 30.581 & .000 \\
Test1 & 1789.001 & 1 & 1789.001 & 22.307 & .000 \\
Combination & 807.768 & 2 & 403.884 & 5.036 & .009 \\
Error & 6175.200 & 77 & 80.197 & & \\
Total & 75715.000 & 81 & & & \\
Corrected Total & 8864.025 & 80 & & & \\
\hline
\end{tabular}

R Squared $=.303$ (Adjusted R Squared= .276)

Table 4 shows the effect of Think-Pair-Share strategy on the academic achievement of science, arts and commercial senior secondary school students in Civic Education in Bayelsa State, Nigeria. After partial out the effect of pre-test scores (Covariate), there was no significant difference in the academic achievement of science, arts and commercial senior secondary school students in Civic Education, ( $\mathrm{F}$ $(3,81)=.009, \mathrm{P}=5.036, \mathrm{p}>.05$, partial eta squared $=.303)$. Since the $\mathrm{p}$-value is less than .05 , we, therefore, reject the stated null hypothesis. Therefore, the result concludes that there is a significant 
effect of Think-Pair-Share instructional strategy on the academic achievement of science, arts and commercial senior secondary school students in Civic Education in Bayelsa State, Nigeria.

\section{Summary of Findings}

From the data analysed, interpreted and results presented, the following is a summary of major findings arising from the study:

1. there is a significant effect of Think-Pair-Share instructional strategy on senior secondary school students' achievement in Civic Education in Bayelsa State, Nigeria. In other words, students taught using Think-Pair-Share strategy outperformed those in the control group.

2. there is no significant effect of treatment (Think-Pair-Share instructional strategy) on the academic achievement of male and female senior secondary school students in Civic Education in Bayelsa State, Nigeria.

3. there is a significant effect of treatment (Think-Pair-Share instructional strategy) on the academic achievement of science, arts and commercial senior secondary school students in Civic Education in Bayelsa State, Nigeria.

\section{DISCUSSION}

The first finding which revealed that there is a significant effect of Think-Pair-Share instructional strategy on senior secondary school students' achievement in Civic Education in Bayelsa State, Nigeria. In other words, students taught using Think-Pair-Share strategy performed better than those taught using traditional (lecture) strategy. This may be an indication of the fact that the students taught Civic Education with the use of Think-Pair-Share strategy leveraged on the social connections (cooperation with others) and interdependence among classmates which is an inherent benefit associated with this strategy coupled with the fact that they were given a reasonable amount of time to individually think about a concept before cross-fertilizing such ideas and thoughts with classmates. In fact, this lends credence to the assertion of Ontario (2005) that Think-Pair-Share strategy enables students to learn better by building on the ideas of classmates.

Empirically, while it can be said that the finding to research hypothesis one partly agrees with the research report of Ofodu and Lawal (2011) which affirms the effectiveness of Think-Pair-Share strategy on one hand, it also contrasted with the said finding when they found that Think-Pair-Share strategy is the second most effective strategy when it is used together with Reciprocal Method in teaching Reading Comprehension among Junior Secondary School students in Ekiti state, Nigeria. In this study, the Think-Pair-Share strategy is found to be the most effective teaching strategy compared to the traditional (lecture) method. Suffice to say that while English Language (Reading Comprehension) and Civic Education are both compulsory school subjects, the difference in the order of effectiveness of Think-Pair-Share strategy may be as a result of the category of participants used for these respective studies in relation to their class of study. That is, Junior Secondary School students may not have attained or acquired the necessary higher order thinking skills required by this strategy compared to Senior Secondary School students.

However, this present finding is in agreement with the findings of Jebur, Jasim and Jaboori (2012) and Utama, Marhaeni and Putra (2013) reported separately that, Think-Pair-Share strategy significantly not only contributed to the high achievement of Basic Education students in General English in a university in Iraq, but it also indicated a significant effect on students' self-confidence and speaking competency in English Language among second grade students in Indonesia. This finding is also in alignment with the findings of Odediji (2013) that students within Ilorin metropolis who were taught Social Studies with Think-Pair-Share strategy performed better in Social Studies than those students 
taught with traditional (lecture) method. This present finding also confirms the findings of Bataineh (2015) and Bamiro (2015) reported in their separate studies that undergraduate students who were examined in Educational Psychology in King Saud University, Saudi Arabia, after been taught with the use of Think-Pair-Share strategy were not only found to obtained higher post-test mean scores compared to those taught with traditional method; but senior secondary students within Abeokuta metropolis taught Chemistry with the use of Think-Pair-Share strategy were also found to record higher post-test scores compared to those taught with a traditional method.

The second finding showed that there is no significant effect of treatment Think-Pair-Share on the academic achievement of male and female senior secondary school students in Civic Education in Bayelsa State, Nigeria. In fact, this finding is in agreement with the findings of some other empirical studies. For example, Odediji (2013) found that there was no significant effect of Think-Pair-Share strategy on the academic performance of students in Social Studies on the basis of gender. Also, Bamiro (2015) reported that in terms of effectiveness, the use of Think-Pair-Share strategy shows no significance on the academic achievement of senior secondary school students in Chemistry based on gender. In a similar vein, Linver, Davis-Kean and Eccles (2002), Dayioğlu and Türük-Asik (2004), Weerakkody and Ediriweera (2008) all reported that female students recorded better scores in Mathematics, and management-based university courses than their male counterparts respectively.

Consequently, the point to be made from the second finding is that both the male and female students that participated in the study did not react differently (in terms of academic achievement) to the teaching intervention in Civic Education through the use of Think-Pair-Share. Put differently, being male or female student does not in any way influence the good or otherwise achievement gain that a student would have obtained in Civic Education Achievement Test. Hence, when both the male and female students in co-educational settings are exposed to the same pedestal of educational opportunities, they are likely to be at their very best academically especially when socio-cultural barriers and stereotyping are removed.

The third finding showed that there is a significant effect of Think-Pair-Share on the academic achievement of science, arts and commercial senior secondary school students in Civic Education in Bayelsa State, Nigeria. This finding is in line with the research report of Duyilemi (1990) who found that significant difference exists between science and non-science students in their academic achievement in Biological taxonomy. The finding disagrees with the findings of Akpan (2010), Hussain, et'al (2011), Udoukpong, Emah and Umoren (2012) and Aina (2013). For example, Akpan (2010) reported that there exists no significant difference in the academic performance of science and art students in Mathematics both in public and private secondary schools in Calabar Township. From the third finding, it can be deduced that science, arts and commercial students that participated in the study did respond differently (in terms of academic achievement) to the teaching intervention in Civic Education through the use of Think-Pair-Share instructional strategy. 


\section{CONCLUSION}

From the findings, it can be concluded that Think-Pair-Share strategy is effective especially in relation to students' academic achievement in Civic Education in Bayelsa State compared to the traditional (lecture) method of teaching frequently used by classroom teachers. Similarly, it can also be concluded that both students' gender and the subject combination does not determine the academic achievement of senior secondary school students in Civic Education in Bayelsa State when Think-Pair-Share strategy is used as the medium of instruction.

Based on the discussion and conclusion, the following recommendations are made:

a. Civic Education and other school subject teachers should endeavour to make use of Think-PairShare instructional strategy in teaching and learning activities in secondary schools instead of the continuous use of traditional (lecture) method. This is because Think-Pair-Share strategy promotes inter-dependency, cooperation, critical thinking, higher order thinking and problem-solving skills as well as social-inquiry research skills among students who have been exposed to them.

b. Faculties of Education in universities, Institutes and Colleges of Education in Nigeria should as a matter of urgency include in the Subject Methodology course content of teacher education and training programmes several innovative and student-centred teaching strategies. This will no doubt, contribute in better equipping the pre-service teachers who after graduation and eventual employment as teachers will bring to bear their professional and pedagogical skills in the process of facilitation of knowledge acquisition in their respective classrooms.

c. Equal learning opportunities should be provided for all students irrespective of gender (whether male and female) or subject combination (whether science, arts and commercial students) by teachers of compulsory school subjects such as Civic Education, English Language and Mathematics. This would be possible when the teacher engages all categories of students in an active learning where students' previous experiences are explored to form or recreate new knowledge. By the same token, teachers are expected to update their knowledge of recently research-proven teaching strategies capable of improving students' academic achievement.

\section{Acknowledgement}

Special appreciation goes to the staff, students and the management of the two secondary schools in Bayelsa state who participated in the study. 


\section{REFERENCES}

Aina, J. K. (2013). Subject area specialization-combination correlation in colleges of education: Effects on students' achievement in physics. Open Journal of Education, 1/3, 113-116.

Akpan, I. M. (2010). A comparative study of performance of science and arts students in mathematics in private and public secondary schools in Calabar, Cross River state (Unpublished B.Sc. Ed. Research Project). Department of Curriculum and Teaching, University of Calabar.

Amstrong. T. (2006). Chapter 1: Academic achievement discourse. Retrieved 25 March 2016 from http://www.ascd.org/publication/books/106044.

Bamiro, A. O. (2015). Effects of guided discovery and think-pair-share strategies on secondary school students' achievement in chemistry. SAGE Open 1-7. D01:10.1177/2158244014564755.

Bataineh, M. Z. (2015). Think-pair-share, co op-co op and traditional learning strategies on undergraduate academic performance. Journal of Educational and Social Research, 1/5, 217-226.

Cohen, L., Manion, L., \& Morrison, K. (2007). Research methods in education. New York: Rutledge Press.

Cooperstein, S. E., \& Kocevar-Weidinger, E. (2004). Beyond active learning: A constructivist approach to learning. Reference Services Review, 32/2, 141-148.

Dayioğlu, M., \& Türüt-Asik, S. (2004). Gender difference in academic performance in a large public university in Turkey. Economic Research Centre, Middle East Technical University, Ankara, Turkey.

Duyilemi, B. O. (1990). The relative effectiveness of cooperative and competitive teaching methods on students' achievement in biological taxonomy (Unpublished Ph.D Thesis). Department of Curriculum Studies and Educational Technology, University of Ilorin, Nigeria.

Education Management and Information System (EMIS, 2017). List of public secondary schools in Bayelsa State as at December 2016. Yenagoa: Bayelsa State Ministry of Education.

European Students Union (ESU, 2010). Student centered learning: An insight into theory and practice. Lifelong Learning Programme. Bucharest: Partos Timisoara.

Geisen, J. (2012). Constructivism: A holistic approach to teaching and learning. Retrieved $17^{\text {th }}$ April, 2016 from htpps://ssl.niu.edu/facdev/programs/handout/constructivism.pdf.

Hussain, A., Azeem, M., \& Sharkoor, A. (2011). Physics teaching methods: Scientific inquiry vs traditional lecture. International Journal of Humanities and Social Science, 1/19, 269-276.

Hollyjamaludin (2012). Chapter two: Basic theory. Retrieved from http//www.hollyjamaludin.blogspot.com.

Jebur, M. S., Jasim, H. H., \& Jaboori, H. R. (2012). The effect of using think-pair-share technique on EFL students' achievement in the course of general English. College of Basic Education, University of Mustansiryah, 823-838.

Jekayinfa, A. A., Mofoluwawo, E.O., \& Oladiran, M. A. (2011). Implementation of civic education curriculum in Nigeria: Challenges for social studies teachers. Nigerian Journal of Social Studies, XIV/1, 147-155.

Ledlow, S. (2001). Using think-pair-share in the college classroom. Centre for Learning and Teaching Excellence: Arizona State University, USA. 
Linver, M. R., Davis-Kean, P.E., \& Eccles, J.S (2002). Influence of gender on academic achievement. Retrieved 18 June, 2016 from http://www.rcgd.is.wnich/edu/it,sra02 fullpaper.doc.

Mafan, A. A.I.N., \& Marhaeni, N. D. (2013). The effect of think-pair-share technique on the english reading achievement of the students differing in achievement motivation at grade eight of SMPN 13 mataram. E-Journal Program Pascasarjan Universitas Pendidikan Ganesha, 1: 1-12.

Nwaubani, O. O., \& Azuh, D. (2014). The adequacy of civic contents in the basic education social studies curricula for effective citizenship training of Nigerian youths. International Journal of Educational Science and Research, 4/1, 35-46.

Obura, C. A., \& Ajowi, J.O. (2012). Students perceptions of career: The influence of academic performance and self-efficacy in Kisumu municipality. Modern Social Science Journal, 1/1, 56-93.

Odediji, E. I. (2013). Effect of think-pair-share instructional strategy on students' performance in social studies in junior secondary schools Ilorin, Nigeria (Unpublished M.Ed. Dissertation). Department of Arts and Social Sciences Education, University of Ilorin, Nigeria.

Ofodu, G. O., \& Lawal, R.A. (2011). Cooperative Instructional strategies and performance levels of students reading comprehension. International Journal of Educational Science, 3/2, 103-107.

Okeahiaham, U. P. (2013). An analysis of the effectiveness of secondary school civic education on the attainment of national objectives in Nigeria (Unpublished Ph.D Dissertation). Department of Educational Leadership, Research and Foundations, University of Colorado, Colorado Springs, USA.

Oludipe, B., \& Oludipe, I. D. (2010). Effect of constructivist based teaching strategy on academic performance of students in integrated science at the junior secondary school level. Educational Research and Reviews, 5/7, 347-353.

Ontario TFO (2005). Co-operative learning: Think-pair-share strategy. Ontario: Queen's printer.

Perveen, K. (2010). Effect of the problem-solving approach on academic achievement of students in mathematics at the secondary level. Contemporary Issues in Education Research, 3/3, 9-14.

Peer, K. S., \& Martin, M. (2005). The learner-centered syllabus: From theory to practice in allied health education. The Internet Journal of Allied Health Science and Practice, 3/2, 1-6.

Randolph, J. J. (2008). Multidisciplinary methods in educational technology research and development. Julkaisuja-Hameenlina: Finland.

Sampsel, A. (2013). Finding the effects of Think-pair-share on students' confidence and participation. Honors Projects, Paper 28. Retrieved $18^{\text {th }}$ June, 2016 from http://scholarworks.bgsu.edu/honorsprojects.

Saskatoon Public schools (2009). Instructional strategies. Retrieved $18^{\text {th }}$ June, 2016 from www.olc.spsd.sk.ac/DE/PD/instr/alphabet.

Richardson, V. (2003). Constructivist pedagogy. Teachers College Record, 105/9, 1623-1640.

Robertson, K. (2006). Increase student interaction with think-pair-share and 'circle charts.' Retrieved $18^{\text {th }}$ June, 2016 from www.colorincolorado.org.

Utama, I. M. P., Marhaeni, A. A.I.N., \& Putra, I.N.A.J. (2013). The effect of think-pair-share teaching strategy on students self confidence and speaking competency of the second grade Students of SMPN 6 Singaraja. E-Journal Program Pascasarjana Universitas Pendidikan Ganesha, 1: 1-10. 
Udoukpong, B. E., Emah, I. E., \& Umoren, S. E. (2012). Student attitudes, parental influence and career aspirations in academic achievement in entrepreneurial curriculum. Academic Research International, 2/1, 527-533.

Weerakkody, W. A. S., \& Ediriweera, A. N. (2008). Influence of gender on academic performance: A comparative study between management and commerce undergraduates in the University of Kelaniya, Sri Lanka. Being Proceedings of the Annual Research Symposium 2008 organized by the Faculty of Graduate Studies, University of Kelaniya. 